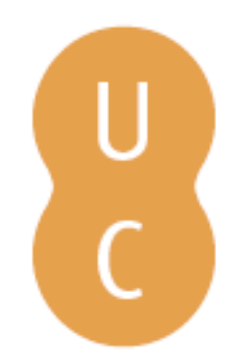

\title{
pommalina
}

\section{O que não cabe nas palavras: peripécia e reconhecimento em Os Maias}

\author{
Autor(es): Deserto, Jorge
}

Publicado por: Imprensa da Universidade de Coimbra

URL

persistente: URI:http://hdl.handle.net/10316.2/37048

DOI: $\quad$ DOI:http://dx.doi.org/10.14195/978-989-26-1043-6_13

Accessed : $\quad$ 26-Apr-2023 13:35:36

A navegação consulta e descarregamento dos títulos inseridos nas Bibliotecas Digitais UC Digitalis, UC Pombalina e UC Impactum, pressupõem a aceitação plena e sem reservas dos Termos e Condições de Uso destas Bibliotecas Digitais, disponíveis em https://digitalis.uc.pt/pt-pt/termos.

Conforme exposto nos referidos Termos e Condições de Uso, o descarregamento de títulos de acesso restrito requer uma licença válida de autorização devendo o utilizador aceder ao(s) documento(s) a partir de um endereço de IP da instituição detentora da supramencionada licença.

Ao utilizador é apenas permitido o descarregamento para uso pessoal, pelo que o emprego do(s) título(s) descarregado(s) para outro fim, designadamente comercial, carece de autorização do respetivo autor ou editor da obra.

Na medida em que todas as obras da UC Digitalis se encontram protegidas pelo Código do Direito de Autor e Direitos Conexos e demais legislação aplicável, toda a cópia, parcial ou total, deste documento, nos casos em que é legalmente admitida, deverá conter ou fazer-se acompanhar por este aviso.

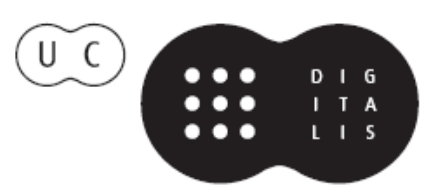


politica no Brasil do sécu

Categorias aristotélicas por Silvestre Pinheiro Ferreira - Musas errantes: tesouros da Antiguidade Clássica no labirinto da Biblioteca Nacional Brasileira - Eudoro de Sousa e a Mitologia • Câmara Cascudo em defesa de Epicuro - Medéia carioca - Ecos de Platão em Vergílio Ferreira - Imaginário clássico na poesia de António Arnaut - Motivos clássicos na poesia novilatina em Portugal: Manuel da Costa - Uma Ifigénia portuguesa: "Noite escura" de João Canijo • Uma leitura de Mau Tempo no Canal de Vitorino Nemésio $\bullet A$ phýsis grega e o Brasil: as viagens de Von Martius $\bullet$ Fantasia para dois coronéis e uma piscina. Ecos clássicos num contexto do séc. XX

\section{A RECEPÇÃO DOS CLÁSSICOS EM PORTUGAL E NO BRASIL}

Maria de Fátima Silva Maria das Graças de Moraes Augusto COORDENAÇÃo 


\section{SÉRIE MITO E (RE)ESCRITA}

ISSN: $2182-8814$

\section{PERIODICIDADE: Anual}

Apresentação: Poetas, pintores, escultores, na Antiguidade, familiarizados com mitos antigos de deuses e de homens, que cristalizavam experiências, interrogaçóes, respostas quanto à existência do homem no tempo e no mundo, em mitos se inspiraram, em contínua criação-recriaçẩo, para neles verterem a sua própria experiência temporal, com todos os desassossegos e inquietaçóes, com todo o espanto, horror ou encantamento pela excecionalidade da ação humana, que rasga ou ilumina fronteiras de finitude. Esses percursos da criação merecem, hoje, a atenção e análise dos Estudos Literários e, como não podia deixar de ser, dos Estudos Clássicos, muito peculiarmente. Importa, pois, proceder à publicação sistemática de estudos deste cariz, que se destaquem pela qualidade científica e pela originalidade, sendo dedicados, sobretudo, a autores de língua portuguesa. Assim se dá corpo à linha editorial MITO E (RE)ESCRITA.

Este livro, realizado no âmbito do Convénio de Cooperação Académica entre o CECH - Centro de Estudos Clássicos e Humanísticos da UC - e o PRAGMA - Programa de Estudos de Filosofia Antiga da UFRJ -, reúne um conjunto de estudos sobre a recepçáo de temas e modelos greco-latinos na literatura e cultura de Portugal e Brasil.

A sua originalidade resulta da participação de diferentes culturas e das especialidades académicas diversas dos investigadores que nele participam, provenientes da Literatura, da Filosofia e da História Antiga. O lapso de tempo abrangido, que vai do séc. XVI ao XX, permite uma visáo de conjunto da evoluçáo operada no perfil cultural de ambos os países e na definição de um trajeto em boa parte comum. 


\title{
O que náo cabe nas palavras peripécia e reconbecimento em $\mathrm{Os}$ Maias
}

(What words do not contain -

peripeteia and anagnorisis in A tragédia da Rua das Flores and in Os Maias)

\author{
Jorge Deserto \\ Universidade do Porto \\ Centro de Estudos Clássicos e Humanísticos da Universidade de Coimbra \\ (jdeserto@gmail.com)
}


Página deixada propositadamente em branco 
Resumo - O objectivo, no presente trabalho, é olhar para Os Maias numa perspectiva, um tanto afastada dos caminhos mais habituais. Em primeiro lugar, ao enunciar alguns sinais que, no romance de Eça, lembram de forma clara a tragédia clássica e, dentro dela, em especial o Rei Édipo, referência fundamental, vai tecendo o seu caminho implacável. Em segundo lugar, ao tratar o modo hábil como Eça resolve o momento da revelação da verdade, ou seja, a ocasião em que alguém vê a sua vida completamente destruída por meio de uma revelação funesta. Veremos que, neste caso, as liçóes da tragédia, embora por caminhos indirectos, não se vêem completamente esquecidas.

Palavras chave - incesto, destino, reconhecimento, peripécia, A tragédia da Rua das Flores

Abstract - This article looks at Os Maias from a particular point of view. First of all, underlining some topics of classical tragedy in Eça's novel, in particular Oedipus the king, it builds its implacable progress. And then, it considers Eça's revelation of the truth, this means, the moment when someone sees his life completely destroyed by a terrible revelation. We will see that models from tragedy, taken in different ways, are not completely forgotten.

KEYwords - incestuous relations, destiny, anagnorisis, peripeteia, A tragédia da Rua das Flores.

\section{Introdução}

O que leva um leitor, nos dias de hoje, a ler Os Maias? Em condiçôes normais, não deveria ser necessário colocar esta interrogação, já que parece indiscutível estarmos diante de uma obra enorme, de um daqueles monumentos que marcam a história literária. Esperaríamos, portanto, que esta fosse uma obra procurada por todos, que naturalmente fizesse parte do património de leitura de qualquer cidadáo. No entanto, há aspectos que nos convocam a uma leitura mais fina desta questão. Antes de mais, trata-se de um romance tão amplo, com uma gama de episódios táo vasta, que os elementos que atraem cada leitor, na irredutível singularidade que subjaz a cada opção de leitura, podem ser os mais variados, nem todos sobreponíveis ou equivalentes. Afinal, este é um romance em que o "objecto de reflexão" dominante é Portugal, um romance que tem como "projecto global" o "de escrever, de explicar Portugal como problema", como afirma Jacinto do Prado Coelho (1976: 188)1. Um projecto tão amplo pode ter o condão de intimidar o leitor.

1 O mesmo autor, ao sublinhar esse largo espectro que o romance abarca, ancora-o, desde logo, num signo para-textual: tanto o título como o subtítulo se apresentam no plural (Coelho 1976: 167). 
Acresce também que, num país com um índice de leitura tấo baixo, a aproximação a Os Maias assume-se, muitas vezes, não como um percurso natural, mas como um obstáculo que se torna necessário ultrapassar. A tudo isto vem juntar-se o papel da escola. Todos os estudantes portugueses que completam o secundário estudam, nas aulas de Português, Os Maias, ou melhor, na maioria dos casos, contornam Os Maias. Nasce aí, frequentemente, uma relaçáo de amor/ódio (em alguns casos, de ódio/ódio) que o tempo não consegue resolver. Em muitos casos, o ensino de Os Maias no secundário redunda numa espécie de ficção, na qual os alunos fingem que leram a obra e os professores tentam desesperadas estratégias para tornar produtivo esse acto de não-leitura. A estrutura episódica da obra acaba por colaborar com esse intento, já que permite a concentração em alguns passos isolados, por regra aqueles que constroem uma imagem irónica da sociedade portuguesa da segunda metade do século XIX: o confronto entre a educação vigorosa de Carlos e a formação tradicional de Eusebiozinho na infância de Santa Olávia, o jantar do Hotel Central, as corridas no hipódromo de Belém, o sarau no teatro da Trindade. Mais do que uma imagem de conjunto, apanham-se instantâneos, nem sempre ligados com solidez, já que não há uma leitura prévia que os una. A exploração obrigatória de uma obra densa e extensa como Os Maias congrega perigos e entrega ao entusiamo do professor a capacidade de fazer dela uma experiência inesquecível - espera-se que pelas melhores razóes. Mas o peso da obrigação ultrapassa, frequentes vezes, a energia dos docentes.

Outra qualidade de Os Maias é o modo como torna enriquecedora qualquer releitura. No processo de preparação deste trabalho, regressei, de um modo sistemático, a uma narrativa que, depois dos tempos de estudante, apenas tinha visitado de forma episódica. Este regresso revelou-me uma outra obra. O que tinha mudado, obviamente, era a minha qualidade de leitor, modificado pelo tempo, amadurecido, mais capaz de sensibilidade a pormenores que, anteriormente, não me tinham prendido a atenção. Um leitor ainda capaz de sentir a emoção que a obra desperta, mas uma emoçáo que agora mais densamente se mistura com a experiência pessoal, feita de ilusóes que o tempo foi erodindo, de expectativas e certezas que a vida foi amaciando, tornando-me, por exemplo, mais sensível ao fracasso daquelas figuras que pretendiam mudar o mundo e que terminam, prosaicamente, a correr atrás de um jantar. Mas é certo que uma obra-prima se define também por esta capacidade de nos permitir que nos leiamos enquanto a lemos: na medida deste critério, Os Maias são, indiscutivelmente, uma obra-prima. 


\section{O que não cabe nas palavras \\ peripécia e reconhecimento em $\mathrm{Os}$ Maias}

Em suma, entre a obrigação e o prazer, entre o cânone e a descoberta, livre e ausente de preconceitos, Os Maias oferecem vários caminhos para um acesso que será sempre uma recompensa. Embora suspeitemos que a este romance caberá muitas vezes aquele lugar, reservado a tantas outras obras maiores da História da Literatura (de Homero, Virgílio e Camóes a Dante ou a Goethe, de Herculano a Garrett ou Camilo, de Proust ou Joyce a Melville ou a Thomas Mann), o lugar onde se arrumam os textos que todos sabemos que devíamos ler, mas que, por variadas razóes e ainda mais variadas desculpas, acabamos efectivamente por não ler.

O meu objectivo, no presente trabalho, é olhar para Os Maias numa perspectiva, em nada inédita, mas um tanto afastada dos caminhos mais habituais. Em primeiro lugar, ao enunciar alguns sinais que, no romance de Eça, lembram de forma clara a tragédia clássica e, dentro dela, em especial o Rei Édipo, referência fundamental - em particular no modo como trabalha a presença de destino, essa força invisível que, na sombra, à revelia da cegueira das personagens, vai tecendo o seu caminho implacável. Em segundo lugar, ao tratar o modo hábil (num sentido que poderia evocar o dexios aristofânico) como Eça resolve o momento da revelaçáo da verdade, ou seja, como resolve a dificuldade de colocar em palavras (e, mais ainda, nas palavras de um narrador) a ocasião em que alguém vê a sua vida completamente destruída por meio de uma revelação funesta. Veremos que, neste caso, as liçôes da tragédia, embora por caminhos mais indirectos, não se vêem completamente esquecidas.

\section{Tragédia: família, incesto, destino}

De entre as muitas razóes que podem levar um leitor a escolher Os Maias como companheiro de viagem, a primeira delas não será, certamente, aquela que nos alerta para a presença neste romance de algumas das características habitualmente associadas à tragédia da antiguidade. No entanto, a dimensão trágica desta intriga, como tem sido já abundantemente sublinhado, é algo de extremamente relevante, seja no que se prende com a sua dimensão de história familiar, seja no que respeita aos amores incestuosos de Carlos e Maria Eduarda, seja no que concerne à força, inalterável e inamovível, do destino. O leitor facilmente encontra ecos de temas que está habituado a considerar quando se debruça, por exemplo, sobre a tragédia grega. Estes apontam, em particular, para ressonâncias de uma obra como o Rei Édipo, o que nâo deve propriamente surpreender-nos, tendo em conta o papel para- 
digmático que a peça de Sófocles foi garantindo ao longo do tempo, ao qual não será alheia a valoração positiva que sobre ela recai na leitura da tragédia que Aristóteles faz na sua Poética.

Entre os aspectos que dão forma a esta leitura, avultam alguns que se impõem de um modo particularmente evidente. Em primeiro lugar, a forma como o romance se assume como uma história de família, claramente denunciada pelo título principal. Os contornos trágicos, como se compreende, não estáo neste puro acto enunciativo: mas já estáo bem presentes no desenvolvimento da acção, na qual um acontecimento trágico, que ensombra uma determinada geração da família, vai alastrar, como uma mancha imparável e incontrolável, à geração seguinte, vítima inocente de algo que começou a ser tecido no tempo dos seus pais. O leitor familiarizado com as intrigas da antiguidade não pode deixar de pensar na história dos Pelópidas ou dos Labdácidas, nas quais também o sangue e o sofrimento se transmitem de geração em geração, numa vertigem imparável e, muitas vezes, incompreensível para os mortais, demasiado vulneráveis na sua fragilidade. O caso da casa de Tebas, como já foi dito antes, é aquele que permite o paralelo mais perfeito, já que, como Édipo, Carlos é claramente vítima de uma situação que, decorrendo do comportamento dos pais, em nada é sua responsabilidade. Esta dimensão de maldição familiar, na qual o sofrimento ameaça sucessivamente geraçóes da mesma família, deixa bem evidente a sua presença no romance de Eça.

Em segundo lugar, é forçoso referir, como motivo central da intriga romanesca - e aquele que lhe confere dimensão trágica - o incesto involuntário. Podemos dizer que este avulta como o motivo trágico por excelência, se nos lembrarmos da centralidade do Rei Édipo - e da sua recepção - na tragédia antiga e no modelo de trágico que Eça tem em mente. No espírito do autor, este tema parece incluir-se num conjunto mais vasto de costumes e paixôes a analisar e dissecar no tecido social português. Em carta ao editor, datada de Novembro de 1877, apresenta o plano daquilo a que, neste momento, chama Crónicas da Vida Sentimental (apud Lima 1987: 199):

Para produzir, porém, um alto grau de interesse - é necessário dar-lhes diversidade. Assim, alguns (volumes) pintarão costumes gerais da nossa sociedade: $O$ Prédio $n^{o} 16$ será o jogo; $A$ Linda Augusta, a prostituição; $O$ Bacharel Sarmento, a educação e as escolas, etc. Outros, serão o estudo de alguma paixão ou drama excepcional: assim $A$ Genoveva é o incesto; Soror Margarida, a monomania religiosa; teremos ainda $O$ 


\section{O que não cabe nas palavras \\ peripécia e reconhecimento em $\mathrm{Os}$ Maias}

Milagre de Vale de Roriz, para mostrar o fanatismo das aldeias; O Bom Salomão dar-nos-á a agiotagem, etc.

O primeiro volume está muito adiantado; hesito: talvez O Desastre $d a$ Rua das Flores, talvez Os Amores de uma Linda Moça. Em todo o caso é o incesto...

Não é difícil partilhar a perplexidade de Isabel Pires de Lima, quando assinala que Eça refere o incesto "como se este fosse um mal social tão generalizado e com tal dimensão entre nós, quanto os outros que ele projecta retratar - o jogo, a prostituição, o fanatismo religioso, a agiotagem, o adultério." (Lima 1987: 199-200). A questão atenua-se se, na linha do pensamento da mesma autora - e de outros que cita, nas páginas seguintes - conferirmos ao incesto uma leitura distinta, que o remete para um valor matricial de extracção literária, fundando uma actualização, nem sempre pacífica, de um modelo claramente clássico, o da tragédia. Voltarei a este tema mais adiante, quando houver ensejo de fazer uma breve comparação entre Os Maias e A tragédia da Rua das Flores. Sirva para já de conclusão a afirmação de que este motivo parece funcionar aqui como gatilho inspirador, à volta do qual se ergue toda a intriga amorosa de Os Maias.

Um terceiro aspecto relevante é o papel que o destino ocupa nesta intriga. Este é um ponto particularmente perturbador, já que esta presença de um elemento do qual está ausente toda a racionalidade não pode deixar de surpreender num romance no qual, ainda que mitigados, são visíveis sinais da presença de princípios do Naturalismo. No entanto, para lá de questóes como a influência da educaçáo ou do meio social (a que o romance náo deixa de dar copioso relevo), há, ao longo da obra, a noção de que uma força, largamente fora do controlo das personagens, trabalha na sombra para que, inevitáveis e irreparáveis, se combinem todos os fios que conduzem ao tremendo desenlace. A presença dessa força, irracional, fora de toda a capacidade de compreensão, limita a possibilidade de os homens serem senhores das rédeas que comandam o seu percurso e expóe claramente as fraquezas de quem se julga senhor de razão e entendimento superiores. Igualmente aqui o paralelo com a tragédia grega, e com o Rei Édipo em particular, se torna novamente relevante: também na obra de Sófocles há uma força invisível e incontrolável que empurra Édipo na direcção do destino que lhe está reservado, com o toque adicional de, no caso do filho de Laio, todos os seus esforços para fugir dessa força se revelarem, afinal, passos que o encaminham para ela - este é um ponto que Carlos, imerso no seu constantemente invocado diletantismo, não poderia seguir. Mas, num e noutro caso, há um aspecto fundamental que se repete e fica evidente com 
clareza - há forças que os seres humanos nitidamente não dominam e que, na sombra, conduzem muito da sua vida. A dúvida que isto lança sobre a capacidade de autodeterminaçáo do ser humano constitui, no caso de Eça, um tópico que não pode deixar de ser lido com uma certa surpresa.

Esta presença do destino aparece, antes de mais, em forma de moldura, deslocada das personagens para as paredes do Ramalhete. A forma como o próprio Vilaça, num íntimo debate entre superstição e racionalismo, apresenta a fama daquela casa (imediatamente desvalorizada por Afonso da Maia) é indiciadora de uma desconfiança que não consegue largar, mesmo sabendo-o alheio ao ar do tempo, o apego a uma tradição de lendas e agoiros tradicionais.

... e por fim [Vilaça] aludia mesmo a uma lenda, segundo a qual eram sempre fatais aos Maias as paredes do Ramalhete, «ainda que (acrescentava ele numa frase meditada) até me envergonho de mencionar tais frioleiras neste século de Voltaire, Guisot e outros filósofos liberais...» Afonso riu muito da frase, e respondeu que aquelas razóes eram excelentes - mas ele desejava habitar sob tectos tradicionalmente seus; se eram necessárias obras, que se fizessem e largamente; e enquanto a lendas e agoiros, bastaria abrir de par em par as janelas e deixar entrar o sol. (Cap. 1)

Mas a verdade é que, no final, depois da morte de Afonso, o próprio Vilaça pode regressar, sem sobressaltos racionais, à demonstração da justeza dos seus receios:

E voltando-se para o Ega, que se sentara, ainda todo pálido, no sofá bordado a matiz, antigo lugar de D. Diogo, [Vilaça] murmurou devagar, gravemente:

- Há três anos, quando o Sr. Afonso me encomendou aqui as primeiras obras, lembrei-lhe eu que, segundo uma antiga lenda, eram sempre fatais aos Maias as paredes do Ramalhete. O Sr. Afonso da Maia riu de agouros e lendas... Pois fatais foram! (Cap. 17)

Esta referência à fatalidade das paredes do Ramalhete - que confere à casa um estatuto de quase personagem - derrotando uma visão racional que, no momento inicial, parecia claramente vencedora, emoldura, como já sublinhei, na sua irrepreensível construção em anel, todo um outro conjunto de referências que apontam para a teia invisível que vai rodeando as 


\section{O que não cabe nas palavras \\ peripécia e reconhecimento em $\mathrm{Os}$ Maias}

personagens, mantendo-as na ignorância ou mesmo embaladas num doce e cego engano.

Mesmo quando se trata ainda dos amores entre Pedro da Maia e Maria Monforte, há já sinais desta temática. Atente-se, por exemplo, no momento em que Afonso, na companhia de Sequeira, vê, pela primeira vez, Pedro na companhia da filha do negreiro:

O Sequeira ficara com a chávena de café junto aos lábios, de olho esgazeado, murmurando:

- Caramba! É bonita!

Afonso não respondeu: olhava cabisbaixo aquela sombrinha escarlate, que agora se inclinava sobre Pedro, quase o escondia, parecia envolvê-lo todo - como uma larga mancha de sangue alastrando a caleche sob o verde triste das ramas. (Cap. 1)

Para lá do valor simbólico daquela sombrinha escarlate, notória premonição do desenlace trágico daquela relaçáo, o leitor familiarizado com o mundo clássico não resistirá a associar aquela "larga mancha de sangue" 2 que alastra à noção de miasma, a mancha poluidora que, ao espalhar-se, contamina todos aqueles que com ela contactam. Não é completamente deslocado, igualmente, que evoquemos a mancha vistosa dos tapetes cor de púrpura que, em Ésquilo, o Agamémnon da tragédia homónima pisa com arrogância, desafiado por Clitemnestra. Também aquela mancha que alastra da boca da casa prenuncia o sangue derramado pelo rei de Argos, prestes a sofrer uma violentíssima morte.

Quando o romance nos narra os amores de Carlos e Maria Eduarda, encontramos uma multiplicaçáo destes sinais. Logo no momento do nascimento de Carlos, a escolha do nome por parte da máe, influenciada pela leitura de um romance, parece trazer consigo um selo fatal:

Para abrandar desde já o papá, Pedro quis dar ao pequeno o nome de Afonso. Mas nisso Maria não consentiu. Andava lendo uma novela de que era herói o último Stuart, o romanesco príncipe Carlos Eduardo; e, namorada dele, das suas aventuras e desgraças, queria dar esse nome a seu filho... Carlos Eduardo da Maia! Um tal nome parecia-lhe conter todo um destino de amores e façanhas. (Cap. 2)

2 O próprio texto retoma a referência e confirma o seu valor simbólico e premonitório. No mesmo capítulo 1, Afonso encontra o filho, que acaba de suicidar-se, "aos pés da cama, caído de bruços, numa poça de sangue que ensopava o tapete." 
Parece um pormenor de nula importância, mas, ao impedir que o bebé tenha o nome de Afonso, há algo que, desde o início, afasta este rapaz de um legado que a solidez do nome do avô, ligado ao carácter forte e severo do patriarca, lhe poderia garantir.

À medida que o romance avança, à medida que vai ganhando forma a aproximação entre Carlos e Maria Eduarda, continuam a surgir sinais de que o destino vai traçando o seu caminho, iludindo as personagens com sinais a cujo significado a sua natural cegueira não permite aceder. De um grupo muito amplo, que poderia multiplicar-se quase infindamente, sublinho alguns nos quais essa cegueira se torna particularmente evidente. Vejase, em primeiro lugar, o momento em que Carlos pela primeira vez sabe o nome daquela mulher que tanto o tinha impressionado:

- Tenha V. Ex. ${ }^{a}$ a paciência de esperar um instantinho que eu vou dar parte à Sr. ${ }^{a}$ D. Maria Eduarda...

Maria Eduarda! Era a primeira vez que Carlos ouvia o nome dela; e pareceu-lhe perfeito, condizendo bem com a sua beleza serena. Maria Eduarda, Carlos Eduardo... Havia uma similitude nos seus nomes. Quem sabe se não pressagiava a concordância dos seus destinos! (Cap. 11)

A proximidade entre os nomes, esse ilusório elo, é, afinal, o símbolo de uma ligação mais profunda, que Carlos não poderia antecipar. Ao mesmo tempo, a teia do destino, ao afastar a Gouvarinho e Dâmaso, ambos ausentes em inesperadas viagens, parece dar a Carlos todo o espaço de que ele precisa para a sua conquista. E, mais uma vez, o vemos a saborear o presente envenenado do acaso com a alegria dos que desconhecem as consequências:

Carlos, só, dentro do coupé, voltando à Baixa, sentia uma alegria triunfante com aquela partida da condessa, e a inesperada jornada do Dâmaso. Era como uma dispersáo providencial de todos os importunos: e assim se fazia em torno da rua de S. Francisco uma solidão - com todos os seus encantos, e todas as suas cumplicidades. (Cap. 11)

Quando a relação ganha força e os dois amantes se instalam na "Toca”, também o quarto que lhes está reservado, com a sua decoração excessiva, se enche de sinais de agouro - para lá do mau gosto, sentimos no ar, palpável, a ameaça: 


\section{O que não cabe nas palavras \\ peripécia e reconhecimento em $\mathrm{Os}$ Maias}

Mas depois o quarto que devia ser o seu, quando Carlos lho foi mostrar, desagradou-lhe com o seu luxo estridente e sensual. Era uma alcova, recebendo a claridade duma sala forrada de tapeçarias, onde desmaiavam na trama de lá os amores de Vénus e Marte. (...) Mas Maria Eduarda não gostou destes amarelos excessivos. Depois impressionou-se, ao reparar num painel antigo, defumado, resultando em negro do fundo de todo aquele ouro - onde apenas se distinguia uma cabeça degolada, lívida, gelada no seu sangue, dentro dum prato de cobre. E para maior excentricidade, a um canto, de cima de uma coluna de carvalho, uma enorme coruja empalhada fixava no leito de amor, com um ar de meditação sinistra, os seus dois olhos redondos e agourentos... Maria Eduarda achava impossível ter ali sonhos suaves. (Cap. 13)

A cabeça degolada no painel, os olhos sinistros da coruja lançam uma sombra evidente sobre aquele momento idílico; apesar da ignorância das personagens, percebemos que algo contamina aquele ninho de amor. Quando, mais adiante, Maria Eduarda visita o Ramalhete, novamente os sinais desafiam a cegueira dos intervenientes:

Aqueles lindos cuidados fizeram-na sorrir, enternecida. Depois reparou no retrato de Pedro da Maia: e interessou-se, ficou a contemplar aquela face descorada, que o tempo fizera lívida, e onde pareciam mais tristes os grandes olhos de árabe, negros e lânguidos.

- Quem é? - perguntou.

- É meu pai.

Ela examinou-o mais de perto, erguendo uma vela. Não achava que Carlos se parecesse com ele. E voltando-se muito séria, enquanto Carlos desarrolhava com veneração uma garrafa de velho Chambertin:

- Sabes tu com quem te pareces às vezes?... É extraordinário, mas é verdade. Pareces-te com minha mãe!

Carlos riu, encantado duma parecença que os aproximava mais, e que o lisonjeava.

- Tens razão, disse ela, que a mamã era formosa... Pois é verdade, há um não sei quê na testa, no nariz... Mas sobretudo certos jeitos, uma maneira de sorrir... Outra maneira que tu tens de ficar assim um pouco vago, esquecido... Tenho pensado nisto muitas vezes... (Cap. 14)

O encanto de Carlos diante das semelhanças enunciadas é, talvez, o mais eloquente exemplo de algo que podemos associar à noçáo de ironia 
trágica, esse evidente descaso entre aquilo que as personagens percebem e o fundo mais negro que, enquanto leitores, começamos a entender.

A acumulação de exemplos, talvez mais extensa do que recomendaria o bom senso, ilustra de um modo que me parece claro uma construçáo romanesca que, em larga medida, assenta algumas das suas traves mais importantes numa noção de acaso, constituído como uma força invisível que inevitavelmente aproxima aqueles que não deviam aproximar-se e que, movendo silenciosamente as peças, contribui para o desenlace trágico. Esta é uma concepção de destino que parece fugir a toda a racionalização. Para os antigos gregos, estes fios que comandavam a vida dos seres humanos eram tecidos por forças que estavam muito acima da efémera existência daqueles que nasciam condenados a morrer e, por isso, tais fios estavam naturalmente afastados da capacidade de compreensão dos mortais e eram inquestionáveis. No mundo de Eça, à medida que os fios entrelaçados começam a tornar-se visíveis, a força do acaso não prescinde completamente da racionalização. Tendo diante de si o quadro terrível da verdade, Ega tenta dar ordem a um mundo que, num repente, parece ter-se virado do avesso. E tenta argumentar, consigo próprio, para bem da sua própria capacidade de acomodar aquele tremendo impacto, que a teia do acaso juntou aqueles que, pela excepcionalidade, sempre naturalmente tenderiam a aproximar-se:

E pouco a pouco aquela luz viva, saída do alto, parecia ao Ega penetrar nessa intrincada desgraça, aclará-la toda, mostrar-lhe bem a lenta evolução. Sim, tudo isso era provável no fundo! Essa criança, filha duma senhora que a levara consigo, cresce, é amante dum brasileiro, vem a Lisboa, habita Lisboa. Num bairro vizinho vive outro filho dessa mulher, por ela deixado, que cresceu, é um homem. Pela sua figura, o seu luxo, ele destaca nesta cidade provinciana e pelintra. Ela por seu lado, loura, alta, esplêndida, vestida pela Laferrière, flor duma civilização superior, faz relevo nesta multidão de mulheres miudinhas e morenas. Na pequenez da Baixa e do Aterro, onde todos se acotovelavam, os dois fatalmente se cruzam: e com o seu brilho pessoal, muito fatalmente se atraem! Há nada mais natural? Se ela fosse feia e trouxesse aos ombros uma confecção barata da loja da América, se ele fosse um mocinho encolhido de chapéu de côco, nunca se notariam e seguiriam diversamente nos seus destinos diversos. Assim, o conhecerem-se era certo, o amarem-se era provável... (Cap. 16)

É ainda o acaso, um acaso ao qual não falta força demiúrgica, capaz de destruir aqueles sobre quem recai, mas um acaso regulado pelas proba- 


\section{O que não cabe nas palavras \\ peripécia e reconhecimento em $\mathrm{Os}$ Maias}

bilidades, um acaso ao qual uma luz de raciocínio vem colocar uma certa ordem. Como se as forças do destino, mesmo se incertas e incontroláveis, se deixassem iluminar por alguma luz e, por serem, apesar de tudo, explicáveis, se tornassem menos obscuras. De algum modo, também o destino se deixa ler por matrizes de natureza social e cultural e, nesse transe, se torna menos ameaçador. Pelo menos, Ega deixa-se repousar nessa explicação, como se os acontecimentos, diante da lógica de um raciocínio, amortecessem o seu peso ameaçador.

De todos os modos, e é este o meu ponto na primeira parte deste artigo, Eça constrói Os Maias como uma intriga trágica largamente devedora de um modelo de tragédia que assenta, largamente, sobre os ombros do Rei Édipo de Sófocles. Seja pela escolha do incesto como motivo do desenlace trágico, seja pela forma como torna Carlos e Maria Eduarda vítimas de um destino que trabalha para os perder, numa intriga em que os erros da geração dos pais vão recair sobre os filhos que cegamente os ignoram. $\mathrm{O}$ destino final de ambos, assim o ditam os tempos e as circunstâncias, não será tão terrível como o de Édipo ou Jocasta. Mas Carlos embarca também para um exílio purificador, do qual regressará episodicamente para contemplar uma Lisboa que não se moveu desde a sua partida. Resta-lhe um vazio que alimenta à força de dinheiro e de interesses fúteis - e essa tragédia, que largamente interessa a Eça, já não tem a ver com o seu amor impossível, essa é a tragédia de uma geração que desistiu de mudar o mundo e se acomodou às suas imperfeiçóes.

Ainda uma nota, antes de passar ao tema seguinte. A tragédia, para cumprir perfeitamente o seu efeito emocional, necessita de concentraçáo, precisa de centrar-se numa acção e de explorá-la de modo a que o espectador ou o leitor não se alheiem e não sejam desviados por outros apelos. Ora, neste romance Eça opta por uma estratégia de diluição, ao constantemente interromper o desenvolvimento da intriga trágica com múltiplos episódios, normalmente carregados de feroz ironia, ao multiplicar as personagens, impedindo que o leitor se prenda apenas àquela teia que vai construindo a aproximaçáo dos dois irmãos e o seu caminho para a revelação de uma terrível verdade. Estes constantes desvios, esta estratégia de mitigação, embora atenuada nos momentos finais, não deixa de estar sempre presente, como é facilmente observável através do episódio cómico do chapéu que Vilaça teima em náo encontrar, que vem quebrar o momento em que avô e neto lidam com a mais terrível das revelaçóes. Eça parece dizer-nos que, nestes tempos contemporâneos, a tragédia se dilui nos vários acontecimentos da vida e não se pode esperar que ela surja, intocada e isenta de contaminação. 
Que, mesmo assim, guarde, como o comprovará qualquer leitor do romance, um poderoso efeito emocional, eis algo que teremos de creditar ao génio do autor da obra.

\section{A revelaçáo da verdade}

$\mathrm{O}$ mais poderoso momento de qualquer intriga de incidência trágica é aquele em que as personagens se vêem, finalmente, diante do poder de uma terrível verdade, até aí desconhecida, que se prepara para mudar completamente o curso das suas vidas. Estes momentos, a que Aristóteles, na Poética, chama peripécia ("a mudança dos acontecimentos para o seu reverso" - 1452a; Valente 2004: 57) e reconhecimento ("passagem da ignorância para o conhecimento, para a amizade ou para o ódio entre aqueles que estão destinados à felicidade ou à infelicidade" - idem, ibidem) são, para o Estagirita, pilares fundamentais na construção de qualquer enredo. E são, igualmente, os momentos mais poderosos em termos emocionais. Todos sabemos como, no Rei Édipo, é extremamente forte todo aquele quarto episódio, no qual Édipo, diante do servo que, em criança, o abandonara, tentando salvá-lo da morte, ouve finalmente as palavras que desvendam toda a sua origem e a enormidade daquilo que o destino para ele traçara. Ouvir a mais funesta das revelaçóes e reagir a ela são momentos delicados, difíceis de colocar em palavras. É exactamente dessa dificuldade que pretendo falar aqui.

Também Eça parece tê-la sentido agudamente. A nossa leitura pode tornar-se mais clara se tentarmos uma breve comparação entre as soluçốes encontradas em A tragédia da Rua das Flores e n' Os Maias. Esta comparação, com todas as suas falhas, particularmente as que decorrem do distinto grau de aperfeiçoamento das duas obras, pode tornar mais evidente a qualidade da soluçáo que o romancista encontra, em Os Maias, para ultrapassar este obstáculo.

Convém sublinhar, previamente, que não pretendo deter-me aqui em toda a polémica que rodeou a divulgação pública de $A$ tragédia da Rua das Flores. Não é meu propósito discutir até que ponto foi sensato dar à estampa uma obra que o autor não trabalhou até ao fim e que, por isso, apresenta sinais evidentes de estar longe da qualidade de outras obras de Eça. A tragédia da Rua das Flores interessa-me apenas pelo modo como esta obra nos pode oferecer um vislumbre de uma etapa num processo criativo que, em Os Maias, é alvo de um aturadíssimo labor. 


\section{O que não cabe nas palavras \\ peripécia e reconhecimento em $\mathrm{Os}$ Maias}

Parece indiscutível que $A$ tragédia da Rua das Flores se apresenta como uma primeira tentativa de Eça lidar com o tema trágico do incesto, sempre na esteira da abordagem sofocliana no Rei Édipo. Que o incesto está no centro da preocupação do autor, pode depreender-se de alguns testemunhos do próprio autor, como já vimos anteriormente e pode confirmar-se nos exemplos seguintes. O primeiro, em carta ao editor, um mês antes da citada anteriormente (apud Matos 1988a: 604)

«...uma das novelas está pronta - é só copiá-la: chama-se o Desastre da Travessa do Caldas - ou talvez, não sei ainda: $O$ caso atroz de Genoveva. Trata-se de um incesto. Dará, creio eu, 200 páginas, ou mais. Alguns amigos a quem comuniquei a ideia dela, e parte da execução, ficaram impressionados, ainda que um pouco escandalizados. Não quero dizer que seja imoral ou indecente. É cruel.»

O segundo, quase um ano depois, em carta a Ramalho Ortigão (apud Matos 1988a: 604):

«Eu tenho justamente um romance que estava à espera de vez: escrevi-o para ser a primeira parte das Cenas, mas além de ser mais volumoso do que o plano das cenas comporta (atinge quase a obesidade do Primo Basílio), não me servia artisticamente como introdução às Cenas. Foi por isso que o substituí pela Capital, que é mais um trabalho de generalidade. $\mathrm{O}$ assunto é grave - incesto; mas tratado com tanta reserva que não choca. Os Amores de um Lindo Moço, título pretensiosamente medíocre. Poderei, pour la circonstance, chamar-lhe: O Brasileiro; o herói é-o. Como arte tem tipos de que gosto - tratados numa nova maneira, a contornos grossos, de forte destaque; incidentes curtos, muito adaptáveis ao folhetim - enfim, o que justamente convém.»

Para lá das hesitaçóes incessantes acerca do título - note-se, no entanto, como parece fugir ao termo 'tragédia' - parece fora de dúvida que o romancista constrói esta intriga à volta de um pilar fundamental, o incesto. Aliás, para estar ainda mais próximo do modelo clássico, trata-se do incesto involuntário entre mãe e filho, ou seja, segue mais de perto as pisadas sofoclianas. Quando chegamos a Os Maias, Eça cria a intriga à volta de dois irmáos, o que, desde logo, anula qualquer espécie de implausibilidade quanto à diferença de idades. Além disso, ao afastar a família Maia de qualquer espécie de dificuldade em termos financeiros, ficam também obliteradas 
todas as questôes materiais que jogavam um papel relevante no enredo de A tragédia... e que lhe conferiam um grau de sordidez que Eça resolve atenuar francamente, conferindo às suas personagens uma elevação que torna mais clara a sua inocência de vítimas de um destino, sem para ele contribuírem com qualquer espécie de mancha. Também aqui, ao lidar, na versão posterior, com personagens elevadas, se aproxima mais dos postulados da tragédia clássica.

É também este aperfeiçoamento de rugosidades, em termos de técnica narrativa, que está presente no momento que particularmente me interessa. Em A tragédia da Rua das Flores, o momento em que Genoveva sabe a verdade, em directo confronto com Timóteo da Ega, tio de Vítor, é colocado diante dos nossos olhos em toda a sua crueza (Queirós 1980: 450-451)

- De onde é, donde? - perguntou Timóteo; respirava com aflição, e a bengala tremia-lhe na mão extraordinariamente.

- Sou da Guarda - disse ela.

Timóteo estacou, imóvel, com os olhos dilatados, murmurou duas vezes:

- Santo nome de Deus! Santo nome de Deus!

- O que é? - fez ela lívida.

- Seu marido? Quem era? (...)

-Porquê? Meu marido? Chamava-se Pedro da Ega.

-Oh, maldita! Maldita! Maldita! - bradou Timóteo. E os seus braços erguidos tinham um tremor, o olhar alucinado, e com uma voz estrangulada, medonha:

- Mas esse homem é Vítor da Ega! É seu filho! Eu sou Timóteo da Ega. Ela levou as máos à cabeça, com um gesto medonho: os olhos saíam-lhe das órbitas, a boca aberta queria gritar; começou a torcer as mãos: a sua trança soltou-se: levou os dedos convulsivamente ao colar, a mola desprendeu-se; e, dando passos vagos pela sala, com sons roucos e terríveis, os braços altos, batendo o ar - foi cair sobre o tapete, com os braços abertos.

A verbalização da verdade, a reacção da Genoveva, a tudo assistimos e, perante nós, a visível dificuldade de as palavras traduzirem o momento que as personagens vivem. $\mathrm{O}$ tremor, o olhar alucinado, medonho, o gesto medonho da mulher, a convulsão, tudo isto resulta simultaneamente pobre e excessivo. Mais adiante, quando é confrontada por Vítor, de novo as pala- 


\section{O que não cabe nas palavras \\ peripécia e reconhecimento em $\mathrm{Os}$ Maias}

vras parecem não chegar para a importância decisiva do momento (Queirós 1980: 454):

- Que é, Genoveva? - gritou, aflito, correndo para ela.

Ela viu-o e recuou, com os olhos dilatados, o corpo inteiriçado, um esgar na boca, medonha - e os seus braços faziam insistentemente sinal que náo! Não! Respirava com um aahn ansioso, de agonia. E os olhos terríveis, pasmados, como mortos, saídos das órbitas, fixavam-se nele, com uma persistência pavorosa.

(...)

E ia para ela - mas ela, abrindo a boca com uma ânsia terrível, soltou num baque súbito um grito:

Maldito! Maldito!

E, olhando num relance, correu à janela e, lançando o corpo sobre o peitoril, atirou-se, com um grito estridente. Vítor sentiu ainda o seu corpo fazer, na rua, como um som baço e mole de um fardo de roupa.

De novo o adjectivo 'medonho' parece representar o cume da representação da emoçáa. A comparaçáo final a propósito da queda do corpo na rua funciona quase como anticlímax de um momento que deveria representar, em termos narrativos, um extremo impossível de dor. As palavras ficam curtas para representar este momento, às emoçôes extremas é difícil domá-las no discurso.

Eça parece ter dado particular conta desta dificuldade. Por isso, em $O s$ Maias constrói uma solução particularmente engenhosa. A mudança de fortuna e todas as revelaçóes que se tornam, na sua sequência, necessárias, tudo isso é colocado às costas da perspectiva subjetiva de Joáo da Ega, de tal modo que nós, enquanto leitores, apenas vemos o que ele vê, apenas estamos presentes quando ele está presente. Isso acontece a partir do momento em que Guimarães revela a Ega a verdade e, poupando-nos sempre ao efeito de choque de uma revelaçáo difícil, leva-nos ao momento em que Carlos conhece a verdade e, mais adiante, à ocasião em que Maria Eduarda também sabe de tudo. Isto acontece em dois momentos distintos e também diversamente construídos.

No primeiro, que envolve Carlos, é a falta de coragem de Ega que o faz evitar contar de imediato ao amigo uma verdade que sabe terrível. Seguimos o modo como Ega luta com essa hesitação, especialmente num momento em que teme ver-se forçado pelas circunstâncias a dizer tudo: 
De resto, não poderia ele ajuntar em si bastante coragem, para contar tudo a Carlos, logo, nessa manhã, claramente, virilmente? Era por fim aquele caso tão pavoroso como lhe parecera na véspera - um irreparável desabamento de uma vida de homem?...

(...)

Justamente Carlos fora correr o transparente da janela. Aí, na mesa de trabalho, colocada em plena luz, ficara a caixa da Monforte, embrulhada no Rappel. E Ega pensou num relance: «Se ele repara, se pergunta, digo tudo!» - O seu pobre coração pôs-se a bater ansiosamente, no terror daquela decisão. Mas o transparente um pouco perro subiu, uma faixa de sol banhou a mesa - e Carlos voltou sem reparar no cofre. Foi um imenso alívio para o Ega. (Cap. 17)

Ega resolve, então, que a revelação se fará através de Vilaça, dando-lhe um cunho oficial, quase burocrático. Exime-se, assim, a estar presente no decisivo momento - e poupa ao leitor a narração desse instante. Ainda temeroso, Ega chega apenas depois, 'passado o barranco', e a narrativa pode já livrar-se desse instante difícil:

E Ega pensava: - «Bem, Carlos já sabe tudo, o barranco está passado!» Mas demorou-se ainda, tirando as luvas e o paletó com uma lentidão cobarde. Por fim, sentindo bater alto o coração, puxou o reposteiro de veludo. Na ante-câmara pesava um silêncio; a chuva grossa fustigava a porta envidraçada, por onde se viam as árvores do jardim esfumadas na névoa. Ega levantou o outro reposteiro que tinha bordadas as armas dos Maias.

- Ah! és tu? - exclamou Carlos, erguendo-se da mesa de trabalho com uns papéis na mão.

Parecia ter conservado um ânimo viril e firme: apenas os olhos lhe rebrilhavam, com um fulgor seco, ansiosos e mais largos na palidez que o cobria. Vilaça, sentado defronte, passava vagarosamente pela testa, num movimento cansado, o lenço de seda da Índia. Sobre a mesa alastravam-se os papéis da Monforte.

(...)

- Que diabo de embrulhada é esta que me vem contar o Vilaça? - rompeu Carlos, cruzando os braços diante de Ega, numa voz que apenas de leve tremia.

Ega balbuciou: 
- Eu não tive coragem de te dizer...

- Mas tenho eu para ouvir!... Que diabo te contou esse homem? (Cap.17)

É já no refluxo da exposição da verdade que Eça leva o seu leitor a defrontar a reacção de Carlos. Como acontece ao longo do romance, o tempo atmosférico contribui para sublinhar a dificuldade do momento. Mas já não é preciso aos adjectivos atropelarem-se e repetirem-se. De facto, o barranco está passado, e agora é já a razão que quer perceber o inominável que está a acontecer. Ainda assim, o leitor que recorde o texto de Sófocles náo pode deixar de notar aqui um eco, bem claro, na troca de palavras entre Ega e Carlos. Quando o Servo está prestes a dizer as palavras que desvendam a verdade, este e Édipo trocam as seguintes palavras (1169-70):

$\Theta \mathrm{E}$.

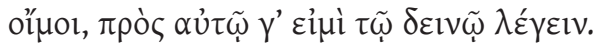

OI.

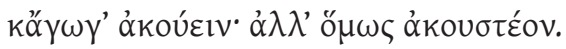

SERVO: Ai de mim, estou perante o mais terrível de dizer! ÉDIPO: E eu de ouvir, mas, ainda assim, tem de ser ouvido.

Édipo e Carlos juntam-se, assim, na mesma busca pela verdade. Quando a conhecem, não vão usar do mesmo modo esse conhecimento. Carlos insiste numa intimidade que sabe ilícita, afunda-se na vergonha dos seus actos, vê o desgosto conduzir o avô à morte. De algum modo, é essa a verdadeira tragédia, o desabar do pilar que, desde o início, nos é apresentado como o alicerce da família Maia.

Finalmente, também Maria Eduarda deverá conhecer a verdade. É igualmente Ega que se encarrega dessa difícil diligência. E, uma vez mais, quando Ega coloca os documentos diante dela, o leitor é poupado ao efeito tremendo da revelação:

...V. Exc. ${ }^{a}$ conhece a letra de sua mãe. É dela esta letra, não é verdade? - É! - exclamou Maria, indo arrebatar o papel.

- Perdão! - gritou Ega, retirando-lho violentamente - Eu sou um estranho! E V. Exc. a náo se pode inteirar de tudo isto enquanto eu não sair daqui.

Fora uma inspiraçáa providencial, que o salvava de testemunhar o choque terrível, o horror das coisas que ela ia saber. E insistiu. 
Deixava-lhe ali todos os papéis que eram de sua mãe. Ela leria, quando ele saísse, compreenderia a realidade atroz... (Cap. 17)

Esta "inspiração providencial" - que quase suspeitamos ser desabafo do próprio Eça, hábil narrador, diante de uma solução feliz - salva-nos também a nós, leitores, de testemunhar o choque, o horror. De algum modo, deixa à nossa imaginação o que se terá passado em seguida, estimula-a, evitando que um momento como aquele seja cercado por palavras que ficariam sempre aquém do verdadeiro sofrimento que pretenderiam traduzir. Ao compararmos esta solução com aquela que Eça havia encontrado em A tragédia da Rua das Flores, percebemos como, no romance posterior, se chega a uma construçáo mais hábil e conseguida. De facto, há momentos em que as palavras, pura e simplesmente, podem estar a mais.

A tragédia grega não é avessa à exposição do sofrimento. Ainda assim, no caso que nos serve aqui de referência - como terá servido a Eça -, após a revelação, Édipo retira-se de cena e tomamos conhecimento dos terríveis acontecimentos seguintes através do relato de um mensageiro que sai do palácio. Há aqui um efeito de mediação, que nos prepara para o surgimento de Édipo no final. Numa linha afim, ainda que sejam também indiscutíveis as diferenças, também Eça decide poupar-nos à narração de um conjunto de momentos nos quais as palavras, por mais trabalhadas que sejam, parecem sempre ser incapazes de desenhar o extremo das emoçóes. Esta habilidade de narrador consumado (que poderíamos, como já disse, aproximar à dexiotes aristofânica) não é coisa menor entre a imensa variedade de apelos que devem continuar a atrair-nos para a leitura de Os Maias. 
O que não cabe nas palavras

peripécia e reconhecimento em Os Maias

\section{Bibliografia}

Coelho, J. P. (1976), "Para a compreensão de Os Maias como um todo orgânico", in Ao contrário de Penélope. Lisboa, Bertrand: 167-188.

Lima, I. P. (1987), As máscaras do desengano. Para uma abordagem sociológica de Os Maias de Eça de Queirós. Lisboa: Caminho.

Luzes, P. (1988), "Incesto fraternal”, in Matos 1988: 346-348.

Matos, A. C. (1988a), “A tragédia da Rua das Flores”, in Matos 1988: 603-606.

Matos, A. C. (org.) (1988), Dicionário de Eça de Queirós. Lisboa: Caminho.

Queirós, E. (1976), Os Maias. Lisboa: Círculo de Leitores.

Queirós, E. (1980), A tragédia da Rua das Flores. Lisboa: Moraes Editores.

Reis, C. (1999), Estudos Queirosianos. Ensaios sobre Eça de Queirós e a sua obra. Lisboa: Presença.

Reis, C. (2009), Eça de Queirós. Lisboa: Ediçōes 70.

Sousa, A. G. (1988), “O incesto n’ Os Maias”, in Matos 1988: 348-351. 
Maria de Fátima Sousa e Silva é Professora Catedrática do Instituto de Estudos Clássicos da Universidade de Coimbra. Desenvolveu, como tese de doutoramento, um estudo sobre a Comédia Grega Antiga (Crítica do teatro na Comédia Grega Antiga), e, desde então, tem prosseguido com investigação nessa área. Publicou já traduções comentadas de nove comédias de Aristófanes, além de um volume com a tradução das peças e dos fragmentos mais significativos de Menandro.

Maria das Graças de Moraes Augusto é Professora Titular no Departamento de Filosofia do Instituto de Filosofia e de Ciências Sociais da Universidade Federal do Rio de Janeiro (UFRJ). A sua investigação sobre História da Filosofia Antiga abrange temas como Platão e a herança platónica, filosofia e conhecimento no pensamento antigo, filosofia e literatura na tradição antiga e recepção dos clássicos gregos no Brasil.

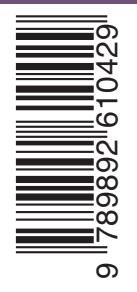


OBRA PUBLICADA

COM A COORDENAÇĀO

CIENTÍFICA
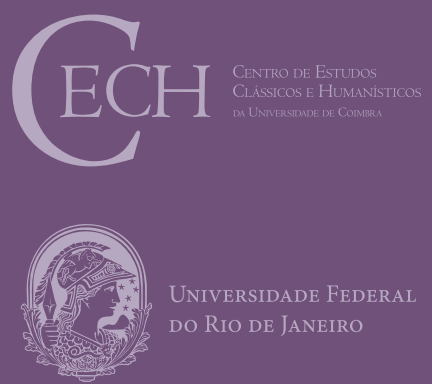

- U 